\title{
ANALYSIS OF REED RESOURCE DYNAMICS IN WATER BODIES OF EASTERN LATVIA
}

\author{
E. Čubars, G. Noviks \\ Latgale Sustainable development institute, Rezekne Higher Education Institution \\ Rezekne, Latvia \\ Ph.: +37128342580, e-mail: edgars.cubars@inbox.lv
}

\begin{abstract}
The paper shows the results obtained during the research of reed dynamics revealing that in Eastern Latvia 20 lakes and pisciculture farms are potentially important for the reed extraction. In 2008, the reed resources there covered a territory of approximately 2300 ha. The ortophoto images of potentially important water bodies made in 1997, 2005 and 2008 were analyzed using the computer program ArcMap. The reed growth develops differently in every water body, but in general the eutrophication of water bodies and the enlargement of reed-covered areas can be observed. The most rapidly the reed occupies new territories in pisciculture farms and shallow lakes. The analysis of reed resource dynamics show that reed-covered areas in this region are expanding every year. The main factors that influence the distribution of reed growths refer to human activities, climatic conditions, hydrological regime in water bodies and natural processes of eutrophication.
\end{abstract}

Keywords: Common reed, biomas energy, dynamics of reed resources .

\section{Introduction}

In Latvia there is no special interest in reeds. They grow on lake and river coasts and in almost every pisciculture farm. Currently, insignificant amounts of reed are used in building. The reeds die off every year and decompose on the coasts of lakes and pisciculture farms creating the emission of $\mathrm{CH}_{4}$ in atmosphere. Nevertheless, as the costs of fossil energy resources are growing, the interest in possibilities of using the local biomass in power supply is also increasing. The previous studies show that reeds can be used as raw material in fuel production. [7,8,9]. Uncertainty about reed stability and capacities of renovation is one of the reasons why reed resources are not used adequately. To evaluate the accessibility of reed resources in future and the influence of using reeds on ecosystems, it is necessary to study the current situation of reed growths and their changes when reeds are not cleared away, in order to obtain data that would allow understanding changes in reed growths after reed extraction. Reeds grow in places where fluctuations of water level are not wider than $50 \mathrm{~cm}$. [2] In many countries the reed Phragmites australis, the most widespread reed in Latvia, is considered to be an invasive species. Reeds form big mono-specific growths that supersede other plants and endanger the biological diversity in biocenosis. There are special reed monitoring and control activities in USA, Canada and Western Europe. To stop the reed invasion, such methods as mechanical removal, drainage, cultivation with discs, granulation, burning, abatement by herbicides and biological control, are used. [3]

In Latvia there is no monitoring system of reed growths. Eutrophication processes are taking place in natural lakes and in artificial water bodies of Latvia, but the intensity of these processes is not clarified. The intensity and the areas of reed invasion in Latvia are not explored yet, there is no information about dynamics of reed growths. To evaluate the reeds as renewable resources, their amount and tendencies of development, the changes of reedcovered areas were analyzed in lakes that are potentially important for reed extraction.

\section{Research object}

Reeds (Phragmites australis) are perennial caulescent plants of grass family. The height can reach $4 \mathrm{~m}$. The stalk is bare, steep, firm and thick (diameter $0.7-1.2 \mathrm{~cm}$ ). The growths are 
usually large, monodominant on the coasts of water bodies and sea, in wetland forests, marshes and moist meadows. Decumbent rootstocks (the length of vegetative nurslings reaches $10-15 \mathrm{~cm}$ ) can rapidly occupy new territories. This plant is characteristic for plant communities in forested fens and overgrown shallow waters (Cl. Phragmitetea, All. Phragmition) and for other plant communities of this class. [1]

The research is made on the dispersion intensity of reeds growing wild in lakes and pisciculture farms of Latgale region.

\section{Materials and methods}

The research on reed dynamics is made in natural and artificial water bodies of Latgale region that are potentially important for the extraction of reed biomass and encompass the whole Latgale region. The research is made in water bodies that are important for reed extraction [10]: Lubana lake, Gumelis, Raznas lake, Feimanu lake, Rusonas lake, Birzkalna lake, Cirisa lake, Kvapanu ponds and Naglu ponds. The changes of reed growths were observed during the period of 1997-2010, using ortophoto images of 1997, 2005, 2008 and 2010 (see the images 1 and 2). The analysis of images was made using the method of distant survey in computer program ARC GIS. During the summer periods, the reed-covered areas were identified in each of the above mentioned lakes.

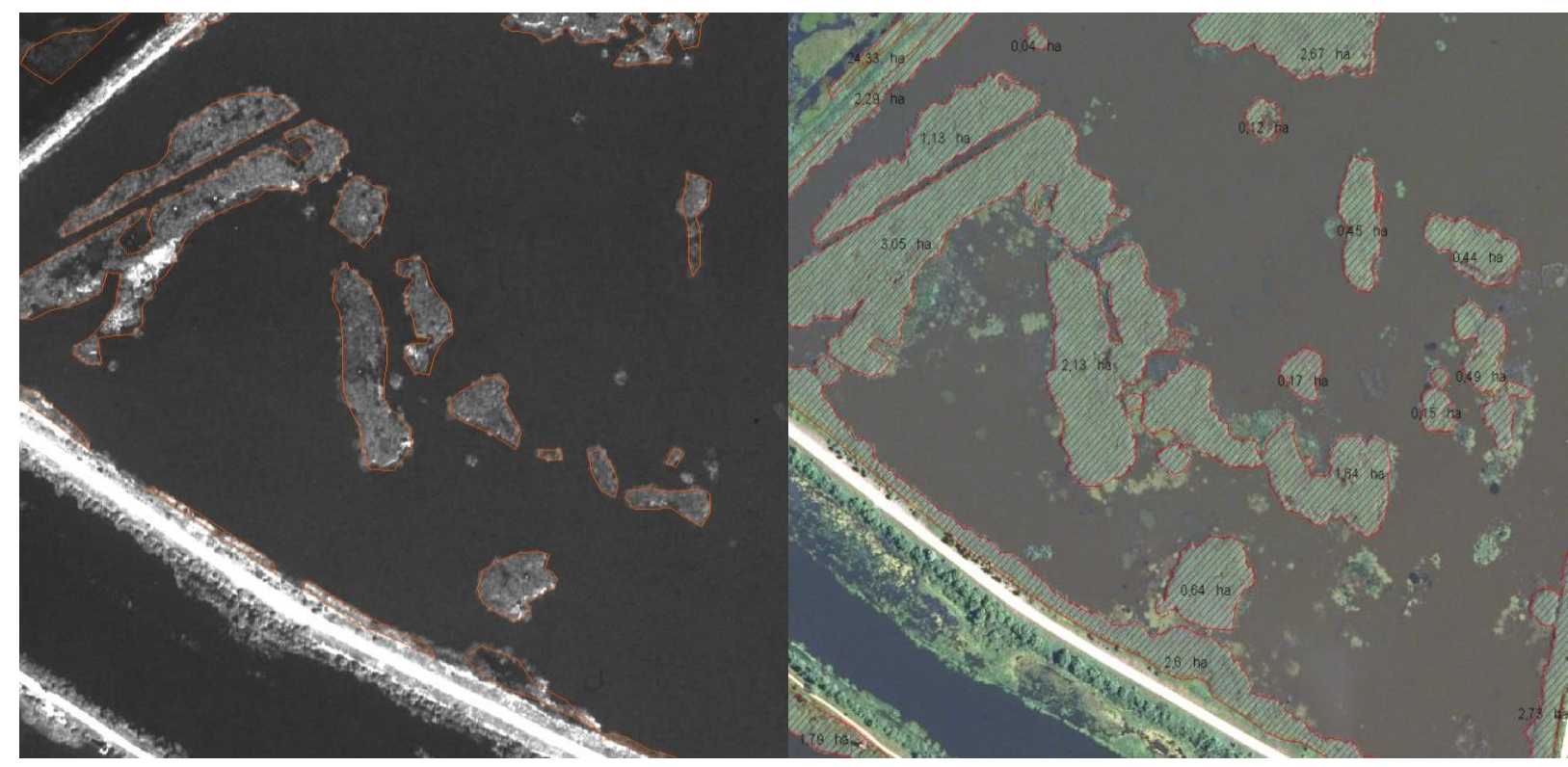

Fig. 1. Reed growths in Kvapanu ponds
Ortophoto of 1997

\section{Results and discussion}

Lakes cover $1,5 \%$ of the territory of Latvia or $1000 \mathrm{~km}^{2}$. 2256 lakes are larger than 1 ha. 16 lakes are larger than $10 \mathrm{~km}^{2}$ and cover $45 \%$ of the total surface of lakes in Latvia. The lakes of Latvia are characterized by eutrophication that often has a negative impact on lake biotopes. The remains of decomposing aquatic plants create the undesirable emission of $\mathrm{CH}_{4}$ in atmosphere. The reed (Phragmites Australis) is one of the most widespread aquatic plants, it occupies larger or smaller areas in all water bodies of Latvia.

Lubanas lake is the largest lake of Latvia. It is the richest in reed resources as well. A rapid enlargement of reed-covered areas can be observed in this lake as reeds occupy new territories in the coastal zone. The lake is comparatively shallow therefore in Lubanas lake, as well as in Kvapanu and Idenas ponds, it is possible to observe the enlargement of reed 
clumps and their merger in more shallow places that are distant from the coast. The ortophotos of 1997 show reed clumps that are growing separately close to each other, whereas ortophotos of 2008 often reveal that these clumps have already merged and are forming joint growths (image 3).

Using the ortophotos of 1997 it was calculated that the read-covered area in Lubanas lake was 440 ha or $5,36 \%$ of the total mirror surface of the lake. The ortophotos of 2005 showed 678 ha of reeds. In average, within one year the reed-covered area had expanded by 29,25 ha or by $0,36 \%$ of the total lake surface. The ortophotos of 2008 revealed reed growths of 734 ha, that is $8,94 \%$ of the total lake surface. The changes of reed growths are demonstrated in image 5.

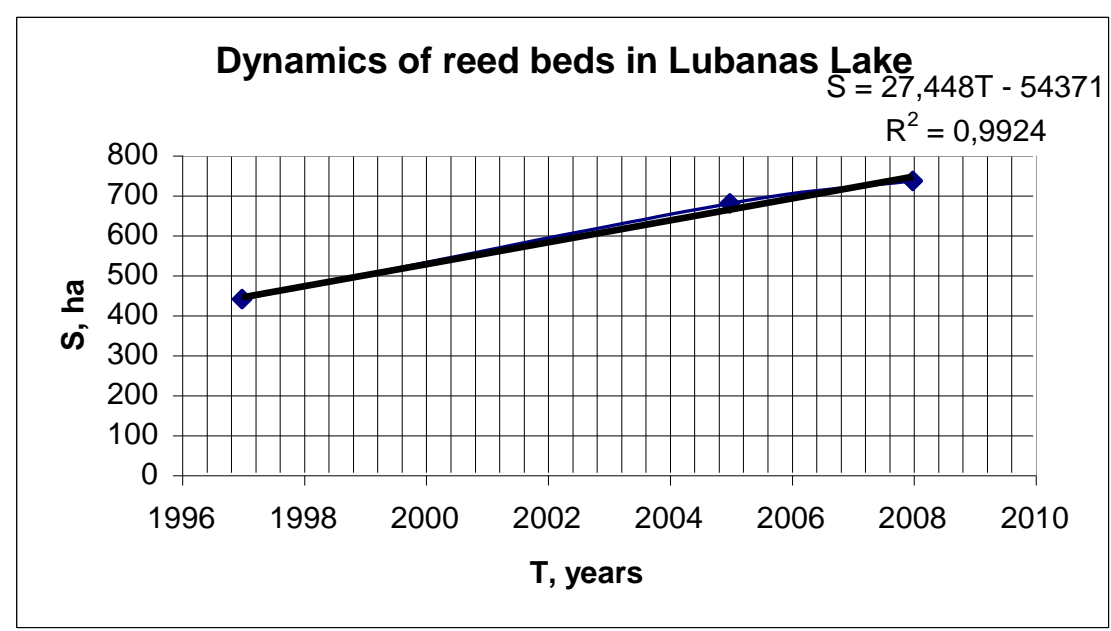

Fig. 3. Changes of reed growths in Lubana lake 1997 - 2008

Kvapanu ponds is one of the biggest pisciculture farms in Latvia. It is composed of 6 ponds with the total surface of 610 ha. The studies of reed dynamics show that the reed-covered areas in Kvapanu ponds are rapidly expanding. The analysis of ortophotos 1997 reveal that reeds cover 74 ha or $12,1 \%$ of the total mirror surface of the ponds. In 2005, 120 ha were covered by reed. In 2008, it was already a territory of 160 ha or $26,4 \%$ of the total surface of the ponds (Image 4$)$. Every year 1,21 ha $(0,21 \%$ of the total surface of the ponds) overgrow.

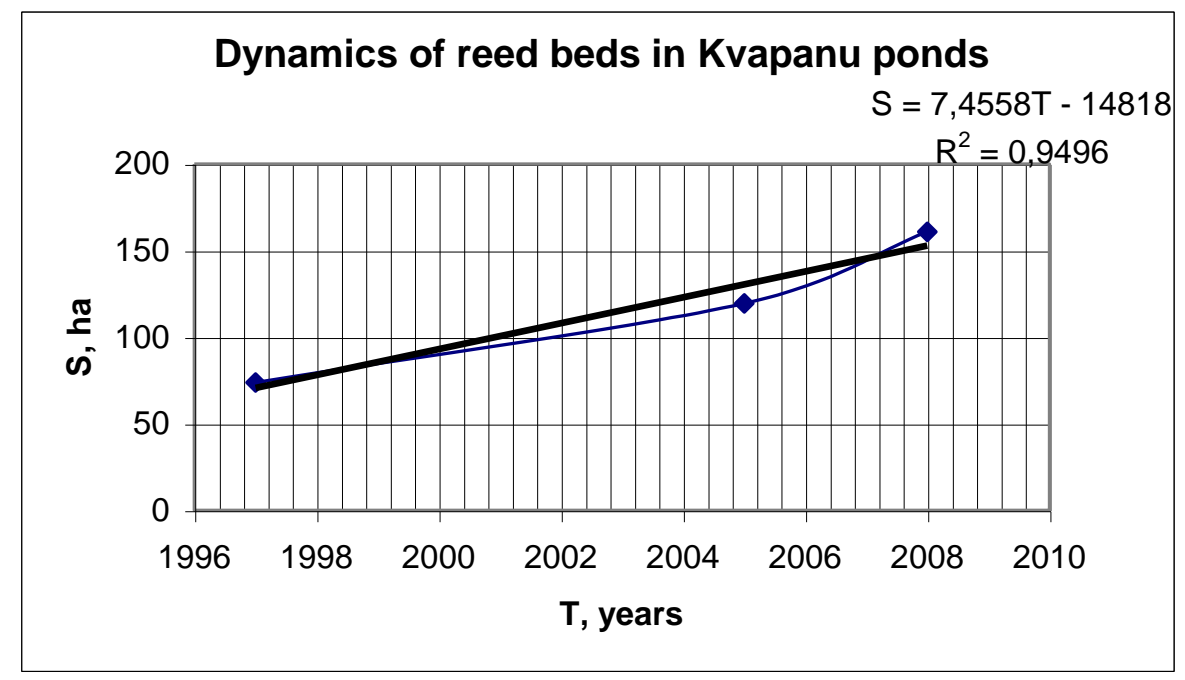

Fig. 4. Dinamics of reed growths in Kvapanu ponds 
In 1997, there were counted 269 separate reed growths with the surface of $0,01-6,38$ ha. In 2008, as the reeds were expanding and the areas were merging, only 106 separate growths were counted. The largest growth covered already 21,2 ha. The reed growths in Kvapanu ponds are presented in image 5. If the reed growths of 1997 and 2008 are compared, a rapid enlargement can be observed.

Gumelis is a specific shallow lake located in the Northern part of Lubanas lake. It is artificially created separating it from Lubanas lake as the result of hydro-ameliorative activities when the Northern dike was built-up. The total surface of Gumelis that in summer season is under water, covers approximately 220 ha. When the water level in Aiviekste river rises, Gumelis and proximal flood-land meadows are regularly flooded. Reed-covered areas in Gumelis are comparatively small. However, a rapid enlargement of reed-covered areas can be observed. This enlargement is one of the rapidest of all the water bodies that are being studied. Analyzing ortophoto images of 1997, in Gumelis there were found 18 ha of reed growths $(8,2 \%$ of the total mirror surface of the water body). Ortophoto images of 2005 showed 33 ha of reeds ( $15 \%$ of the total surface). In 2008, the reeds covered 50 ha $(22,7 \%$ of the total surface of the water body) (Image 6).

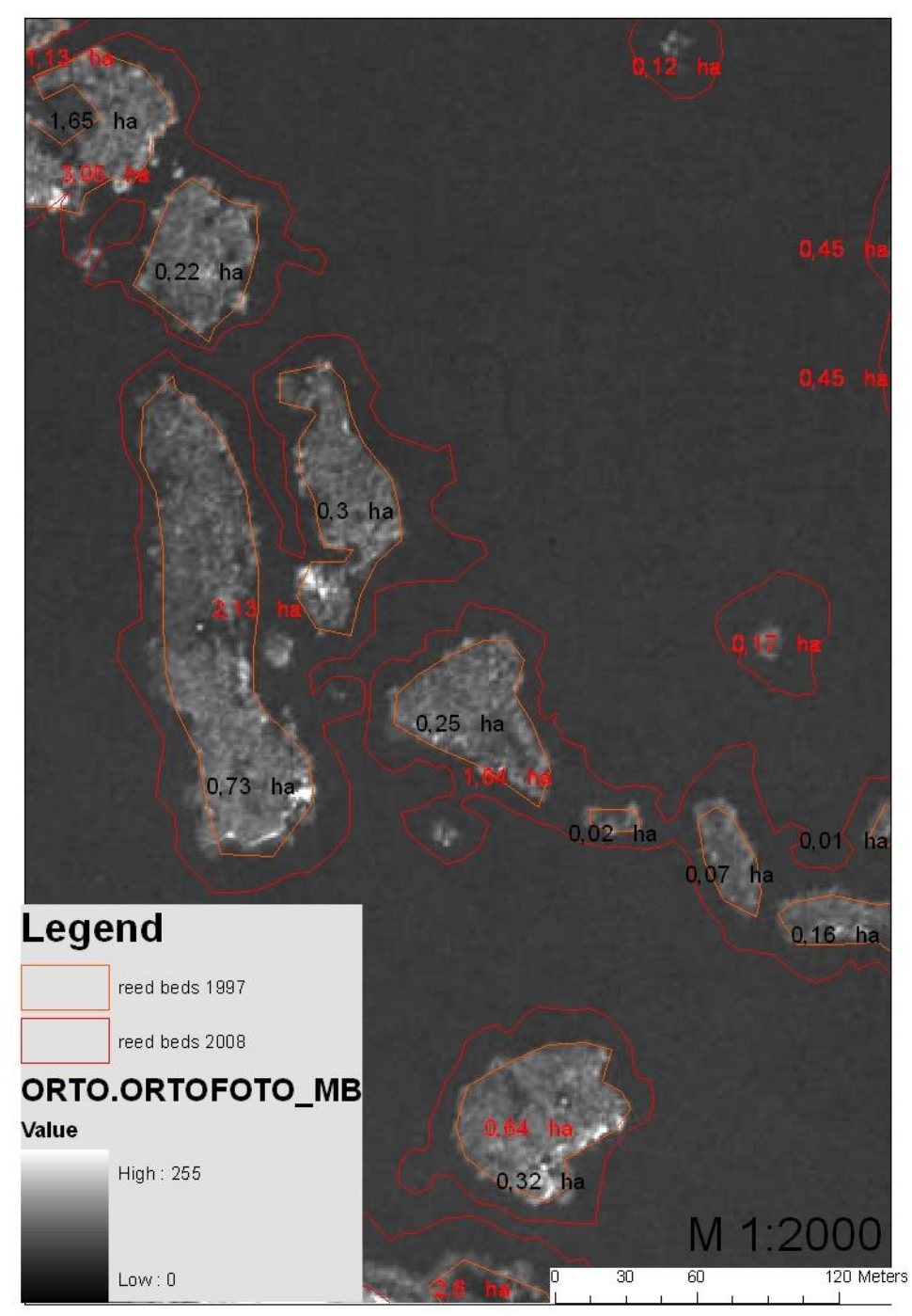

Fig. 5. Reed growths in Kvapanu ponds 


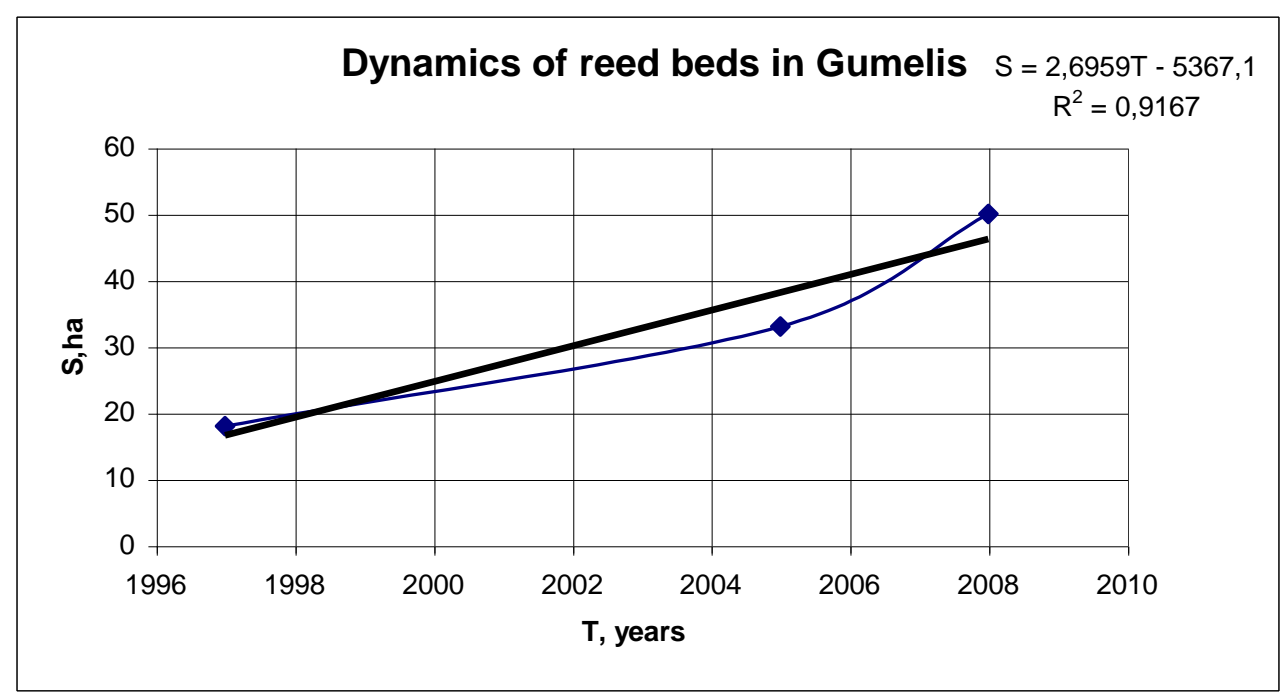

Fig. 6. Dynamics of reed growths in Gumelis 1997 - 2008

On average, the reed-covered surface is expanding annually by 2,9 ha or $1,3 \%$ of the total surface of the lake. Naglu ponds are an important complex used for the fish breeding. The total mirror surface of the ponds is approximately 960 ha. (In the research only 11 ponds, located between Rezekne river and Canal, were analyzed). Unlike in Kvapanu ponds, in Naglu ponds there is an active fish farming, that is why the ponds are regularly drained and flooded again as the result of technological process of fish farming. Therefore why such a rapid enlargement of reed-covered areas as in Kvapanu ponds, cannot be observed. In 1997, ortophoto images of pisciculture farm showed the reed growths of 47 ha, while in 2005 the reed growths were already 54 ha and in 2008 - 62 ha (see image 7). In 1997 they covered $4,9 \%$ of the total mirror surface, in $2005-5,6 \%$ and in $2008-6,5 \%$. It can be seen that the enlargement of reed-covered area is insignificant if compared with Kvapanu ponds. However the general tendency remains and the reed-covered areas are expanding.

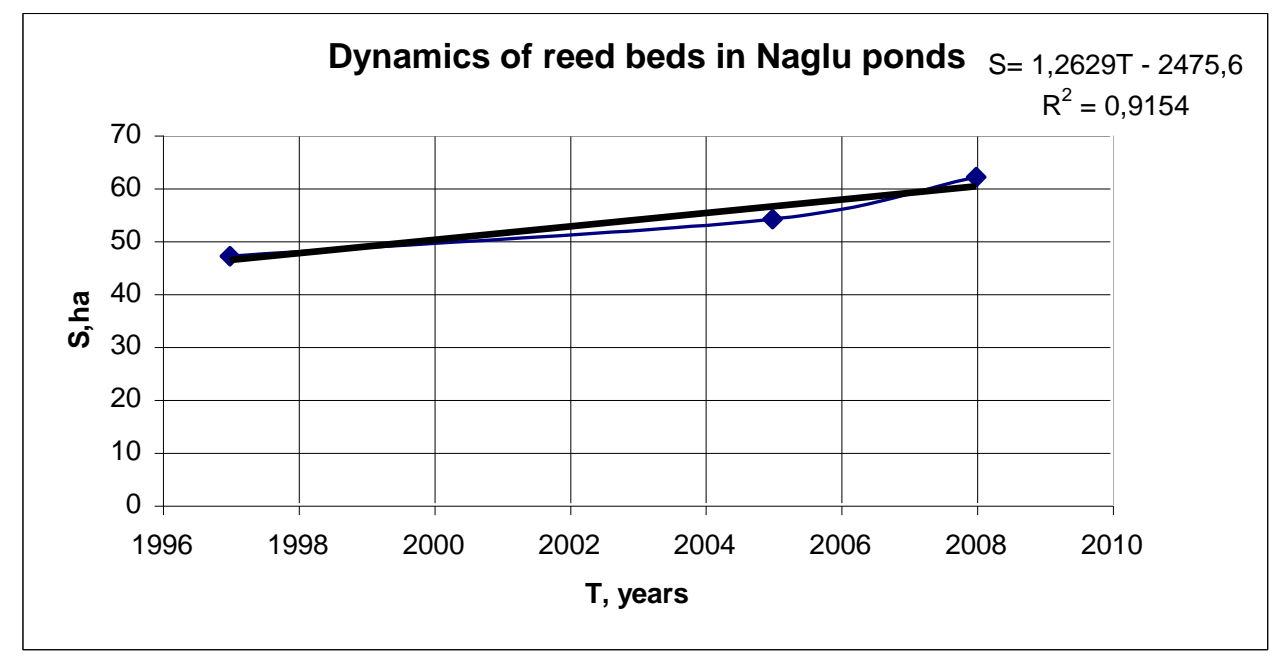

Fig. 7. Dynamics of reed growths in Naglu ponds 1997-2008

Raznas lake is the second largest lake in Latvia with significant reed growths on the coast. Ortophoto analysis of 1997 showed that reed growths covered 256 ha of Razna lake (4,4\% of the total mirror surface of the lake). In 2005, the growth had expanded and covered already 
277 ha $(4,8 \%$ of the total surface), while in 2008 they covered 290 ha (5\% of the total surface). The changes of reed-covered areas are presented in image 8 .

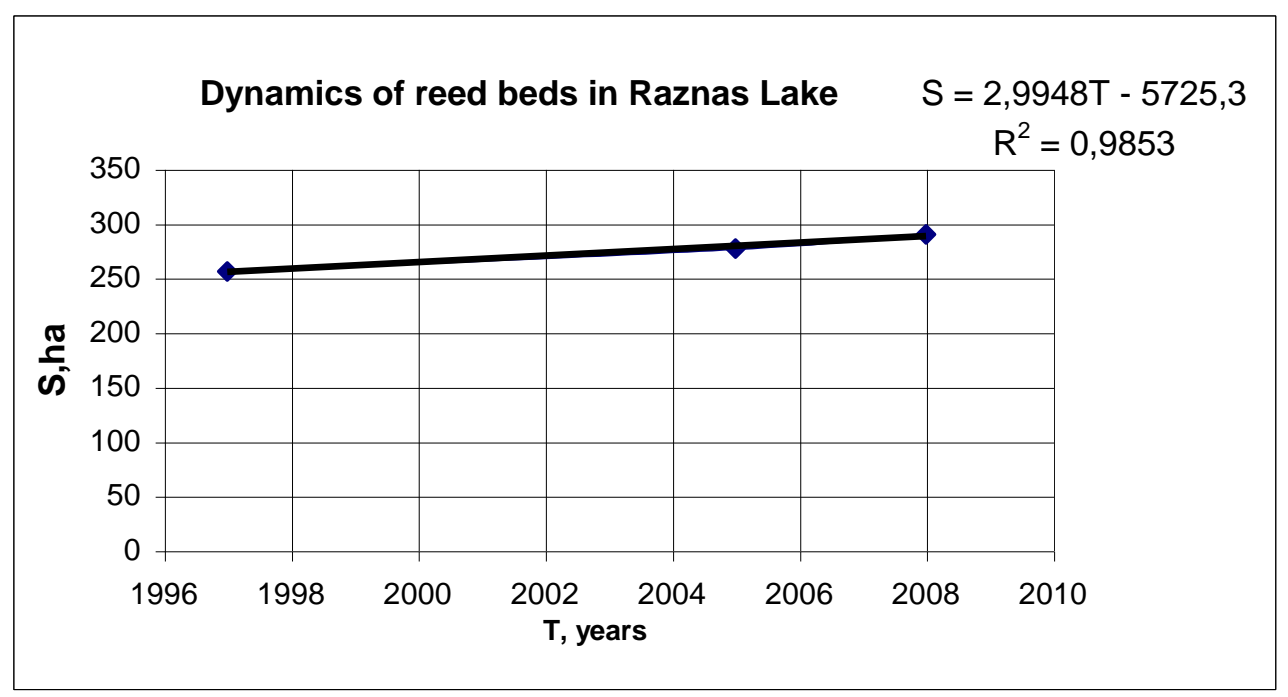

Fig. 8. Dynamics of reed growths in Raznas Lake 1997 - 2008

The reed-covered surface of Raznas lake is expanding annually by approximately 3 ha.

Feimanu lake is located in the bloc of Rusonas lakes and it is quite shallow. If compared with the lakes and pisciculture farms situated in the bloc of Lubana, the reeds are dispersing much slower in Feimanu lake. In 1997, ortophotos showed reeds on 82 ha. In 2005, they covered 83 ha, while in 2008 they covered 85 ha (see image 9).

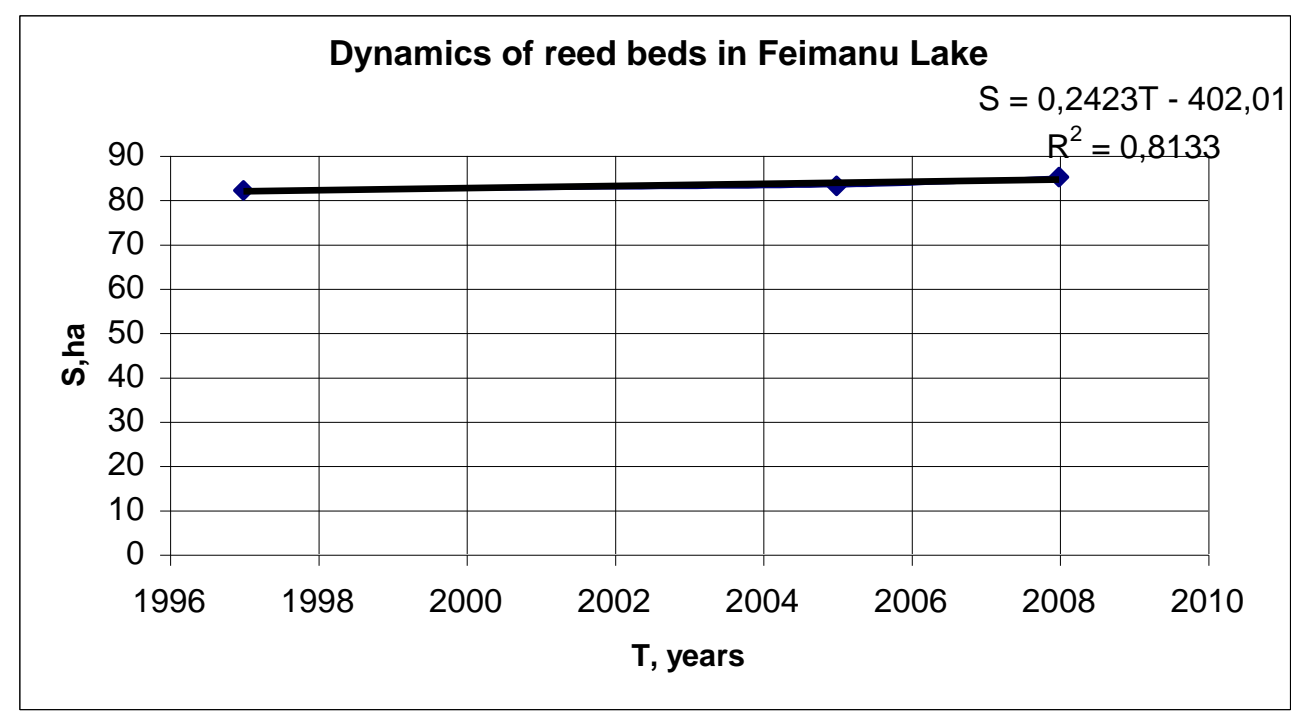

Fig. 9. Dynamics of reed growths in Feimanu Lake 1997 - 2008

In 1997, the total overgrowth of Feimanu Lake covered 13,1\% of the mirror surface. In 2005, the reed-covered surface was $13,3 \%$ and in $2008-13,6 \%$. It can be seen that the enlargement is comparatively insignificant: in 11 year period the reeds have occupied only $0,5 \%$ of the total lake surface.

Rusons is one of the largest lakes in Latgale region. It is one of the richest in resources as well. The reed-covered areas have expanded more rapidly than in Feimanu Lake. In 1997, ortophotos showed that reeds covered 212 ha, in $2005-218$ ha, in $2008-261$ ha and in 
2010 - already 279 ha (see image 10). The total overgrowth of the lake has enlarged by $2,9 \%$ of the total surface: from $8,9 \%$ in 1997 to $11,8 \%$ in 2010.

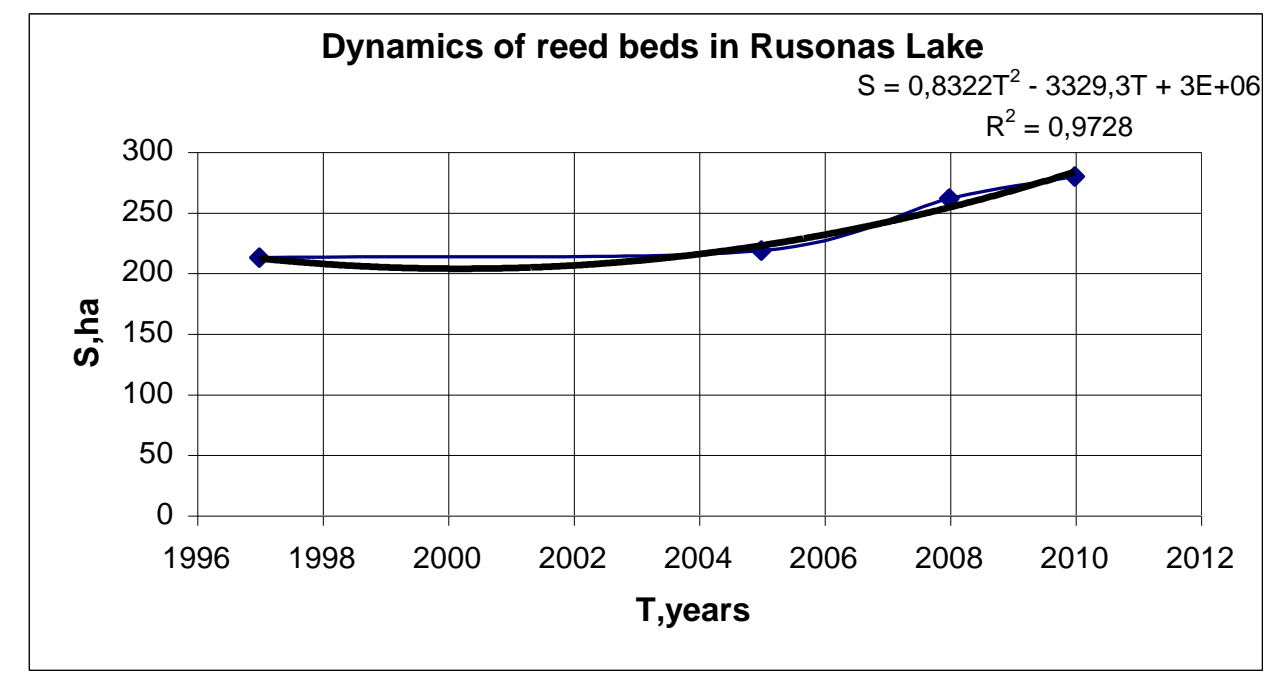

Fig. 10. Dynamics of reed growths in Rusonas Lake 1997 - 2010

Birzkalna lake is comparatively shallow and it is located in the bloc of Rusonas lakes. The total surface of this lake is 272,2 ha, average depth $-2,7 \mathrm{~m}$, maximal depth $-3,9 \mathrm{~m}$. It is a running-water lake. Reed-covered areas are comparatively small. In 1997, the reeds covered 25 ha $(9,2 \%$ of the total lake surface), while in 2010 they had occupied 30 ha $(10,9 \%$ of the total lake surface) (see image 11). The total overgrowth of the lake had enlarged by $1,7 \%$.

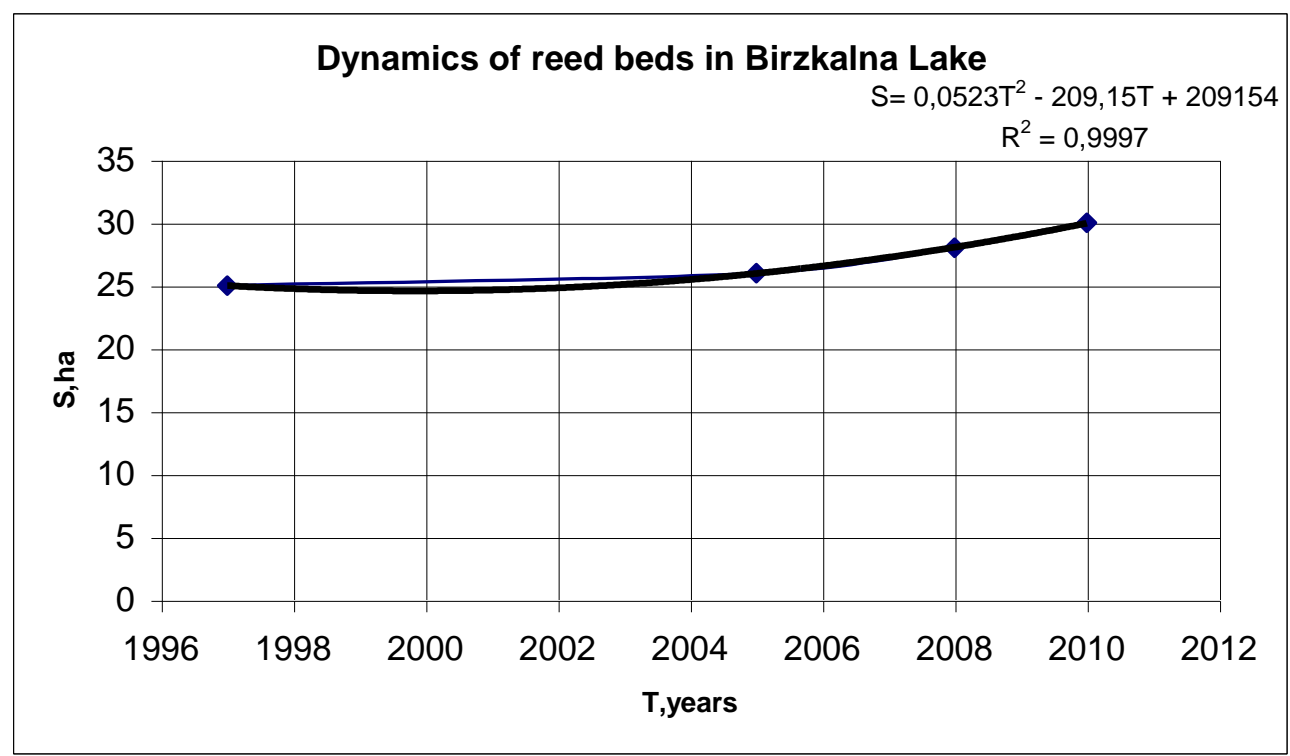

Fig. 11. Dynamics of reed growths in Birzkalna Lake 1997 - 2010

A comparatively small enlargement of reed-covered area can be observed in Cirisa Lake as well. The total lake surface is 630,6 ha, average depth $-4,1 \mathrm{~m}$, maximal depth $-10 \mathrm{~m}$. It is a running-water lake. Ortophoto analysis of 1997 showed that reeds covered 61 ha of Cirisa Lake $(9,7 \%$ of the total lake surface). In 2005, reeds covered 63 ha (10\% of the total surface), in $2008-66 \%(10,5 \%$ of the total surface), in $2008-66$ ha $(10,5 \%)$ and in $2010-67$ ha $(10,6 \%)$ (see image 12$)$. 


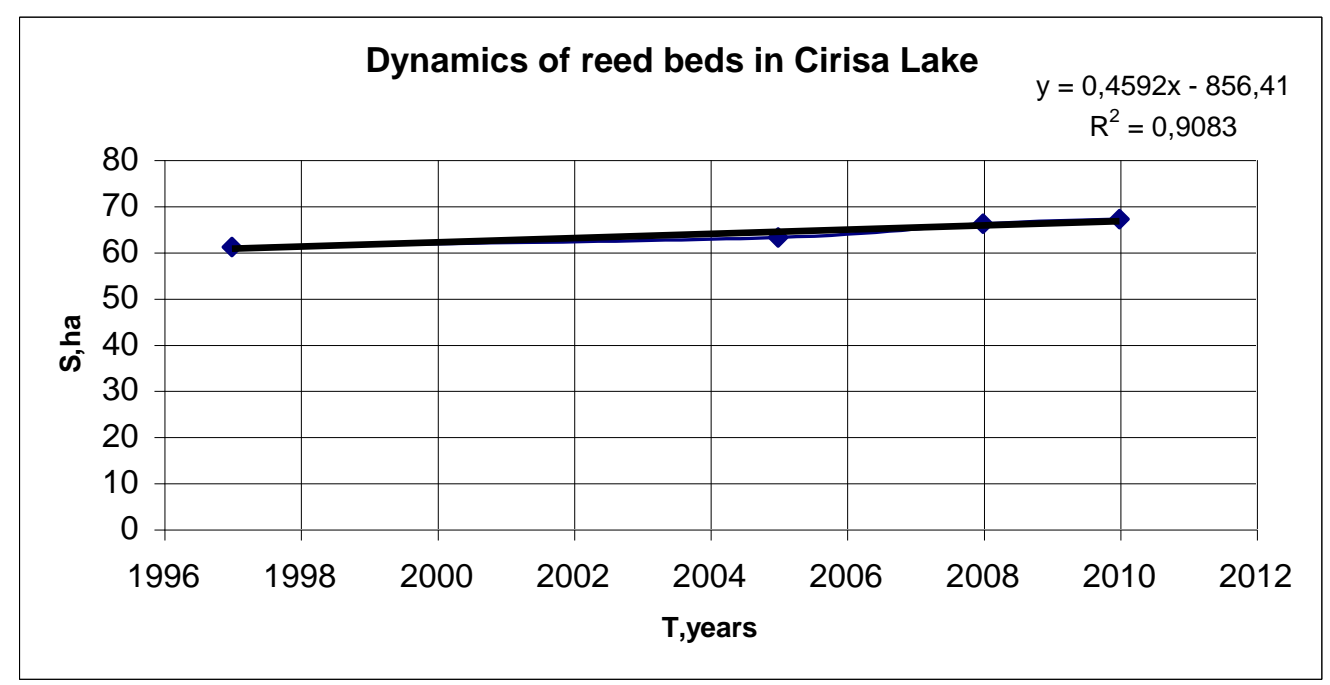

Fig. 12. Dynamics of reed growths in Cirisa lake 1997 - 2010

Like in other lakes of this bloc, the total overgrowth of the lake is comparatively small. During 13 years it has enlarged by 0,9\% from 9,7\% in 1997 to 10,6\% in 2010.

In all the lakes that were studied, the enlargement of reed-covered areas was observed but it should be mentioned that the intensity of this enlargement was different (see image 13).

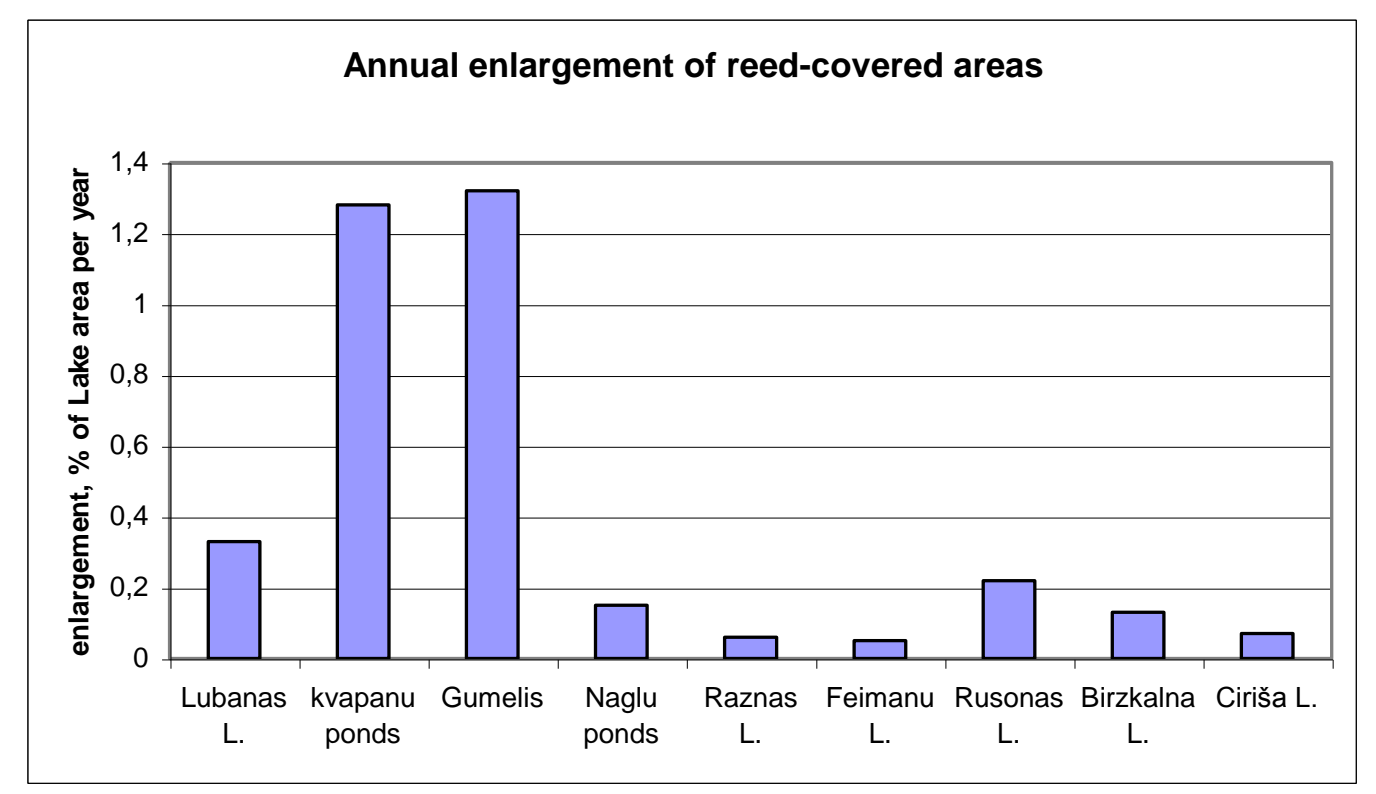

Fig. 13. Annual enlargement of reed-covered areas

If compared with the lakes located nearby, the rapidest enlargement of reed-covered areas could be observed in Rusonas lake where the total surface of reed growths had expanded by 64 ha during 13 years (see image 14) that is 2,9\% of the total lake surface or $0,22 \%$ per year. The smallest enlargement of reed-covered areas was observed in Feimanu lake where in 11 year period the reeds have expanded only by 3 ha or $0,5 \%$ of the total lake surface. In Birzkalna lake and Cirisa lake the enlargement has been a little bit faster. In Birzkalna lake the reed growths have expanded by 5 ha $(1,7 \%$ of the total lake surface) during 13 years, while in Cirisa lake they have expanded by 6 ha $(0,9 \%$ of the total lake surface). 


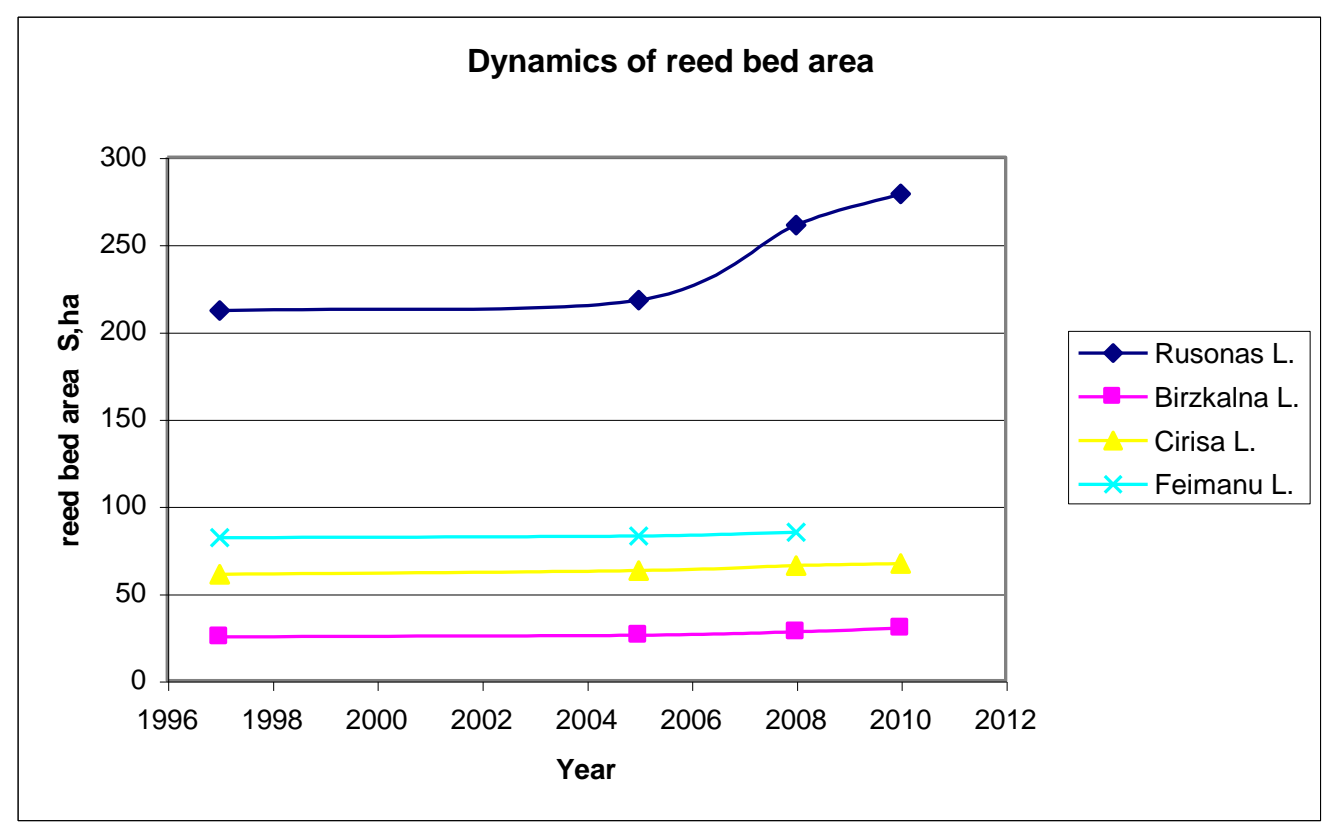

Fig. 14. Enlargement of reed growths in Rusonas and proximal lakes

In the water bodies located in the bloc of Lubanas, the reeds have expanded much faster (see images 15 and 16). During 11 years the reeds in Lubanas lake have expanded by 294 ha $(3,6 \%$ of the total lake surface). The rapidest enlargement of reed-covered areas was observed in Gumelis and in Kvapanu ponds. During 11 years the reed growths in Kvapanu ponds have enlarged more than twice, the ponds are overgrowing quickly. In 2008, the reeds covered already $26,2 \%$ of the total surface of the ponds.

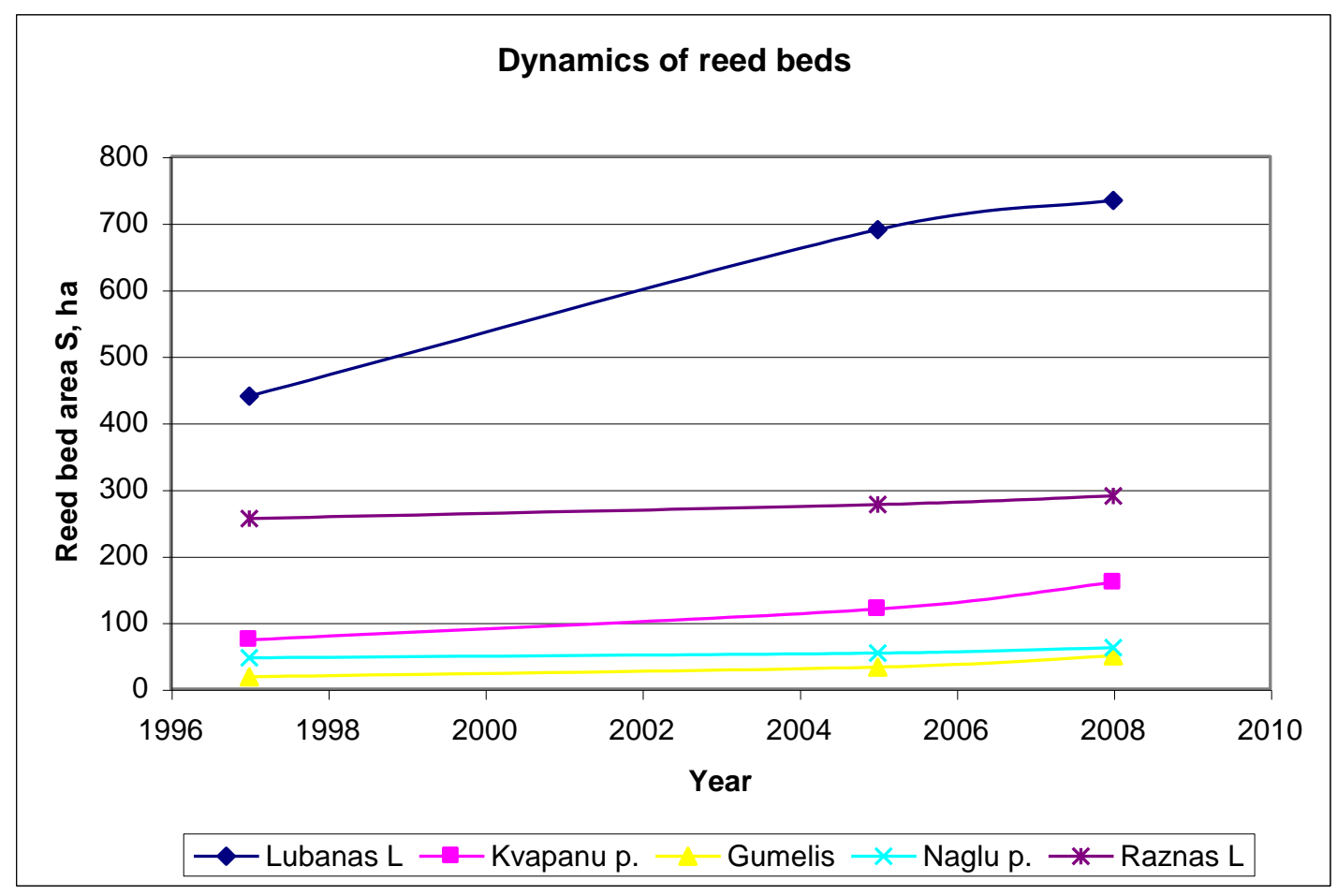

Fig. 15. Enlargement of reed growths in the lakes of the bloc of Lubana

During the given period, the reed-covered areas in Gumelis have expanded by 38 ha ( $18 \%$ of the total surface of the water body). The total overgrowth covers $22,7 \%$ of the total 
surface. If this tendency continues, Kvapanu ponds and Gumelus due to their shallowness will completely overgrow and paludify in 60 years.

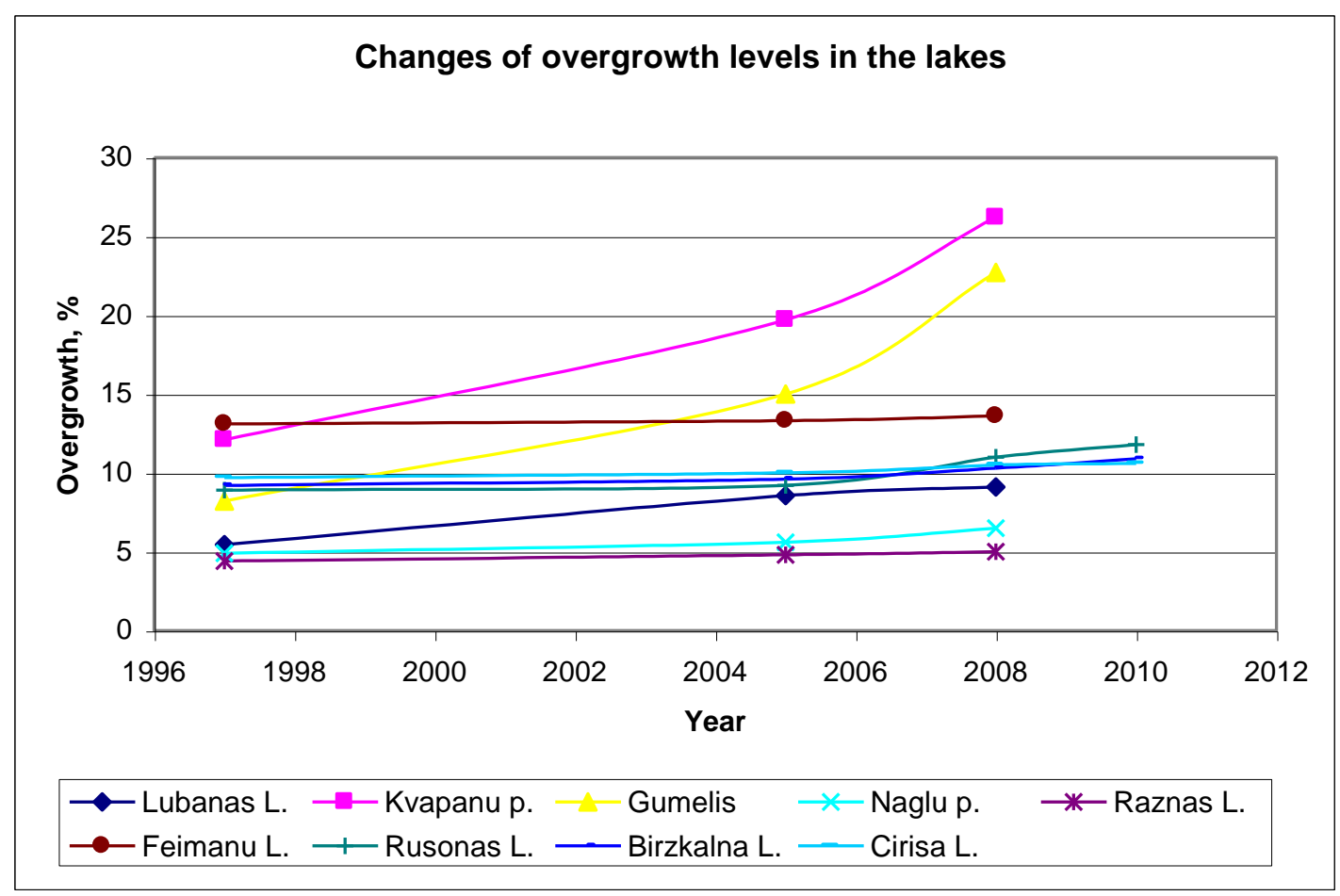

Fig. 16. Changes of overgrowth levels in the lakes

The changes in Naglu ponds are comparatively small. The total reed-covered area have expanded by 15 ha or by $1,6 \%$ of the total surface. The fast limitation of reeds could be the explained by the commercial activities in the ponds where the water level is periodically lowered and then raised again dwarfing the dispersion of reeds in new territories.

The reed-covered areas in Raznas lake have enlarged comparatively slowly. During 11 years they have expanded by 34 ha $(0,6 \%$ of the total lake surface).

\section{Conclusions}

1. In all the lakes and water bodies that are studied, the reed-covered area is expanding every year, the lakes are gradually overgrowing. The intensity of reed dispersion differs in every water body.

2. The annual enlargement of reed-covered areas ranges from $0,05 \%$ to $1,5 \%$ of the total surface of water bodies. The rapidest enlargement of reed-covered areas is observed in Gumelis and in Kvapanu ponds. If this intensity of dispersion maintains, in 60 years Kvapanu ponds and Gumelis will completely overgrow.

3. The reeds are forming large monodominant growths that supersede other species of plants and reduce the biological diversity in lakes and artificial water bodies. Separate reed growths and clumps merge and form one-piece reed areas. The reeds of shallow water bodies are expanding not only in the coastal zone but in the whole aquatorium. The capacities of reeds to occupy new territories depend on the depth of the water body.

4. The richest reed resources are concentrated in Lubanas lake, Kvapanu ponds, Raznas lake and Rusonas lake that are the most perspective for the reed extraction.

5. Since 1997, the total enlargement of reed-covered areas in the 9 lakes that are studied, covers 542 ha. It indicates a stable augmentation of reed resources. 


\section{Acknowledgements}

The investigation was supported by European Social Fond project "Support for Implementation of Doctoral Study Programs at Rezekne Higher Education Institution" (Number of contract 2009/0161/1DP/1.1.2.1.2/09/IPIA/VIAA/007), "IEGULDĪJUMS TAVĀ NĀKOTNË".
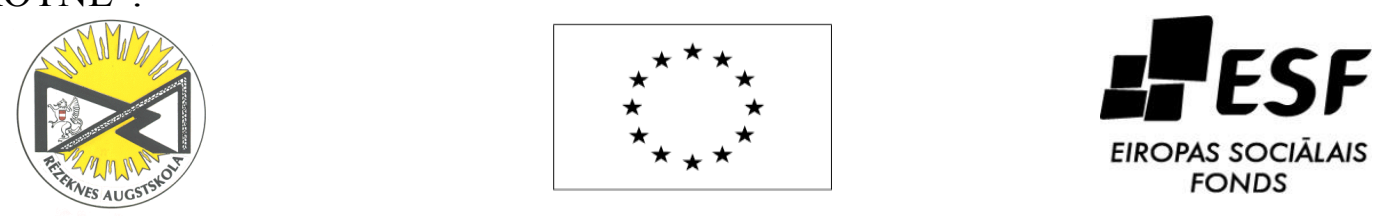

\section{References}

1. http://www.latvijasdaba.lv/augi/phragmites-australis-cav-trin-ex-steud/](10.02.2010)

2. http://www.issg.org/database/species/ecology.asp? $\mathrm{fr}=1 \& \mathrm{si}=301$

3. Back,C.L, Holomuzki J.R „Long-term spread and control of invasive, common reed in Sheldon Marsh, Lake Erie"Ohio Journal of Science, Volume 108, Dec. 2008, p.-108-112 http://www.freepatentsonline.com/article/Ohio-Journal-Science/214526722.html (10.02.2010)

4. Blossey, B. 2002. Biological Control of non-indigenous plants. Cornell University: http://www.invasiveplants.net/phragmites/problem.htm (10.02.2010).

5. Schwarzlander m, Hafliger P. „Shoot Flies, Gall Midges, and Shoot and Rhizome Mining Moths Associated with Common Reed in Europe and Their Potential for Biological Control" Proceedings of the X International Symposium ons Biological Control of Weeds 4-14 July 1999, Montana State University, Bozeman, Montana, USA, p.397-420 http://www.invasive.org/publications/xsymposium/proceed/05pg397.pdf (10.02.2010)

6. Afonin, A.N.; S.L. Greene; N.I. Dzyubenko, A.N. Frolov (eds.). 2008. Interactive Agricultural Ecological Atlas of Russia and Neighboring Countries. Economic Plants and their Diseases, Pests and Weeds[Online]. Available at: http://www.agroatlas.ru.(10.02.2010)

7. Čubars E., Noviks G. (2009). Evaluation of Reed Resources in the Lubanas Lake and substantiation of their use in energy production. Environment. Technology. Resources. Proceedings of the 7th International Scientific and Practical conference June 25-27, 2009 Vol.1. Rēzekne, 66.-74. (2009).

8. Komulainen M., Simi P., Reed energy-Possibilities of using the common Reed for energy generation in southern Finland, reports from Turku University of applied sciences 67, Turku, 19.-20. (2008).

9. Lindh T., Paappanen T., Kallio E. Production of reed canary grass and straw as blended fuel in Finland [Electronic source] -http://www.vtt.fi/inf/julkaisut/muut/2005/vtt_reed_canary1.pdf- (15.01.2010).

10. Čubars E. "Research of Reed Resource Energy Efficiency and Territorial Location for Sustainable Bio Energy Production and Development of Infrastructure in Latgale Region, RTU zinātniskie raksti. 14. sêr., Ilgtspējīga telpiskā attīstība. - 1. sēj. (2010), 67.-71. lpp. [Online]. Available at: https://ortus.rtu.lv/science/lv/publications/8939. 